\title{
Expression of Evi-1 Gene in Leukaemia: Diagnostic and Prognostic Perspective
}

\author{
Ifeyinwa Maryann Okafor $^{1^{*}}$ and Henshaw Uchechi Okoroiwu ${ }^{1}$ \\ ${ }^{1}$ Haematology Unit, Department of Medical Laboratory Science, University of Calabar, Calabar, \\ Nigeria.
}

\section{Authors' contributions}

This work was carried out in collaboration between both authors. Author IMO, conceived the article, performed literature search, wrote initial manuscript draft. Author HUO performed literature search, drew figures and edited the manuscript draft. Both authors read and approved the final manuscript.

Article Information

DOI: $10.9734 / A R R B / 2021 / v 36 i 130337$

Editor(s):

(1) Dr. Gonzalo Emiliano Aranda Abreu, Veracruzana University, Mexico.

Reviewers:

(1) Enrique Wulff, Inst Ciencias Marinas Andalucia ICMAN, Spain. (2) Aixia Dou, Second Hospital of Shandong University, China. Complete Peer review History: http://www.sdiarticle4.com/review-history/65245

Review Article

Received 10 December 2020

Accepted 14 February 2021

Published 19 March 2021

\begin{abstract}
Leukaemias are malignant neoplasms characterized by disorderly, purposeless proliferation of white blood cells with abundance of one cell type. The exact aetiology of leukaemias is still yet to be fully understood. However, it is generally believed that neoplasm is caused by genetic mutation, chromosomal translocation, or activation of certain oncogenes. There are also nuclear oncogenes which are also vital genes in normal cell proliferation and differentiation, often being pivotal genes in developmental and cell cycle regulation. They are also important in cancer progression. Ecotropic viral integration site (EVI-1), a nuclear oncogene has been implicated in the progression of some leukaemias. EVI-1 gene is located on the human chromosome 3 band q24-q28 and spans over $100 \mathrm{~kb}$. The EVI-1 gene encodes a $145 \mathrm{kDa}$ protein of the zinc-finger family which is an essential transcription factor for appropriate murine and human development and is also associated with some leukaemias, following ectopic expression. EVI-1 protein is divided into two main regions: The $\mathrm{N}$-terminal region that contains zinc finger domains (ZFi) and $\mathrm{C}$-terminal region containing three zinc finger domains (ZFii) and a sequence of acidic amino acid. This review summarizes the biological, leukaemogenetic/oncogenic roles and biochemical properties of EVI-1. It further discusses the diagnostic and prognostic implication of EVI-1 in some leukaemias, encouraging incorporation of routine assay of EVI-1 in diagnosis and prognostic monitoring of leukaemias.
\end{abstract}


Keywords: EVI-1 gene; EVI-1 protein; leukaemia; cancers; haematological malignancies.

\section{LIST OF ABBREVIATIONS}

\begin{tabular}{|c|c|}
\hline HIVIAIDS & Human immunodeficiency virus/ \\
\hline & $\begin{array}{l}\text { Acquired } \\
\text { syndrome. }\end{array}$ \\
\hline$E V I-1$ & Ecotropic viral integration site 1. \\
\hline DNA & Deoxyribonucleic acid. \\
\hline IL & Interleukin. \\
\hline NSF & $\begin{array}{l}\text { : N-ethylmaleimide sensitive fusion } \\
\text { protein. }\end{array}$ \\
\hline MuLV & : Murine leukaemia provirus. \\
\hline MCF & : Mink cell focus-forming. \\
\hline$C B-1$ & $\begin{array}{l}\text { : Cannabinoid receptor interacting } \\
\text { protein } 1 .\end{array}$ \\
\hline LTR & Long terminal repeat. \\
\hline RNA & Ribonucleic acid. \\
\hline$A M L$ & Acute myelogenous leukaemia. \\
\hline RUNX1 & Runt-related transcription factor 1. \\
\hline$B C R$ & Breakpoint cluster region. \\
\hline$A B L$ & Abelson murine leukaemia virus. \\
\hline$S C L$ & Stem cell leukaemia. \\
\hline$J A K$ & Janus kinase. \\
\hline STAT & $\begin{array}{l}\text { Signal transducer and activator of } \\
\text { transcriptional protein. }\end{array}$ \\
\hline JNK & c-JUN N-terminal kinase. \\
\hline$C M L-B C$ & $\begin{array}{l}\text { Chronic myelocytic leukaemia in blast } \\
\text { crisis. }\end{array}$ \\
\hline MDS & Myelodysplastic syndrome. \\
\hline EPO & Erythropoietin. \\
\hline TGF & : Transforming growth factor. \\
\hline
\end{tabular}

\section{INTRODUCTION}

Cancer is one of the leading cause of death globally, accounting for 7.6 million deaths (about $13 \%$ of all death) in 2008 , and it is projected to continue rising, with an estimate of 13.1 million deaths in 2030 [1]. Worldwide, cancer deaths are more than the percentage of deaths caused by HIVIAIDS, tuberculosis and malaria put together. It is the second leading cause of death in developed countries and it is among the three leading causes of death for adult in developing countries [1]. In the United States of America, an estimated number of 565,650 deaths occurred in 2008 as a result of cancer, representing $23 \%$ of total mortality that year [2]. In 2002, there were 6.7 million cancer deaths worldwide with less than $5 \%$ of these in Sub-Saharan Africa. About $70 \%$ of all cancer deaths in 2008 occurred in low and middle income countries [1].

Leukaemias are malignant neoplasms characterized by disorderly, purposeless proliferation of white blood cells with an over abundance of one cell type. It is a disease of the blood forming tissues particularly the bone marrow. It is usually recognized in blood smear by the presence of many abnormal white blood cells [3]. The cancerous cells clone will grow rapidly and at the expense of normal haematopoietic cells. The neoplastic cells will take nutrients from normal haematopoietic tissues and grow more rapidly than normal bone marrow cells $[4,5]$. The existence of leukaemia has been known for more than 150 years. In 1859, Rudolf Virchow, the father of cell theory, found the presence of many white blood cells in people suffering from leukaemia. He called such blood "weisses blut" (white blood) [3]. A vital discovery came in 1868 when Ernst Neuman [6] reported changes in the bone marrow in leukaemia and established the link between the source of blood and bone marrow. With the work of Erlich, [7], leukaemia was classified into myeloid group (emanating from the myeloid lineage) and lymphoid group (emanating from the lymphoid lineage).

Leukaemia and cancer in general is proving to be more complex and molecularly diverse than ever imagined, yet the present era is one of optimism that its conquest may be approaching. This apparent oxymoron has come about as a result of dramatic advances in our understanding of carcinogenesis, many derived from research into the pathogenesis of haematological malignancies. Although the exact aetiology of leukaemias is unknown, it is agreed that neoplasm is caused by genetic mutation, frequently a chromosome translocation, or activation of certain oncogenes [8-10]. A number of physical, chemical, and biological agents have been implicated in the mutations [3]. Nuclear oncogenes are not only important in cancer progression but are also vital genes in normal cell proliferation and differentiation, often being pivotal genes in developmental and cell cycle regulation. Interestingly, a specific nuclear oncogene, Ecotropic viral integration site [EVI-1], encodes a protein of the zinc-finger family which is an essential transcription factor for appropriate murine and human development and is also associated in some leukaemias, following ectopic expression [11].

The EVI-1 gene was originally detected as a consistent insertion site in retro-virus induced experimental murine leukaemias and is a member of the large family of nuclear zinc finger [12]. EVI- 
1 gene encodes a zinc-finger, deoxynucleic acid (DNA)-binding protein originally described as the transforming gene associated with a common ecotropic vital insertion site in myeloid leukemia [13] but not in normal marrow or cord blood cells. Experimental studies suggests EVI-1 blocks cellular differentiation by binding to GATA-1 or other specific DNA sequences controlling gene expression and may be involved in the pathogenesis of acute myeloid leukemias [14-16]. This review summarizes the biological roles and biochemical properties of EVI-1 in normal and malignant haematopoiesis, and also evaluates its diagnostic and prognostic properties in haematological malignancies.

\section{EVI-1 GENE AND PROTEIN}

The EVI-1 gene is located on the human chromosome 3 band q24-q28 and spans over 100 $\mathrm{kb}$. The gene contains 12 exons with 10 coding exons [17,18]. Exon 1 to exon 5 of the gene spanned about $50 \mathrm{~kb}$. Overall, the EVI-1 sequence consists of $267 \mathrm{bp}$ of 5 non coding sequence and $167 \mathrm{bp}$ of 3 ' non-coding sequence. The rest part of the gene consists of an open reading frame [17].

The EVI-1 gene encodes a $145 \mathrm{kDa}$ protein, EV1protein. The EVI-1 protein is divided into two main regions: The $\mathrm{N}$-terminal region that contains zinc finger domains (ZFi) and C-terminal region containing three zinc finger domains (ZFii) and a sequence of acidic amino acid. The two regions are separated by a proline- rich region in the middle [19] (Fig. 1). In vitro study [20] showed that 3 of the zinc finger domains on the $\mathrm{N}$-terminal can bind with specific sequence of 15 nucleotides: (CT)AAGA(CT)AAGATAA. Another study [20] reported that the Zinc-finger domain of the C-terminal can recognize and bind a specific sequence of GAAGATGAG.

\section{EVI-1 GENE - PROPERTIES}

EVI-1 was originally identified as a common site of viral integration in the DNA of AKXD murine myeloid tumours [21]. Fordham [11] stated that AKXD recombinant inbred mouse strains are derived from mating $A K R / J$ and $D B A / 2 J$ strains which have a high or low incidence of lymphoma respectively. These strains have a range of tumour incidence and have proved invaluable in identifying common sites of retroviral integrations which may represent novel proto-oncogene loci. A particular strain, AKXD-23, was found to develop myeloid tumours at high frequency. The
DNA from all the AKXD-23 myeloid tumours examined had a common ecotropic retroviral integration in the same locus, termed ecotropic viral integration site 1 (EVI-1). Subsequent studies identified a putative proto-oncogene, EVI1 , activated by provirus in IL-3 dependent myeloid leukaemia cell lines [12].

Mucenski et al. [21] and Bergeron et al. [22] showed in their studies that EVI-1 rearrangements have also been detected in myeloid cell lines and leukaemias in NFS/N or $\mathrm{NFS} / \mathrm{N}$ hybrid mice injected as neonates with wild mouse ecotropic MCF MuLV and Cas-Br-E MuLV. Retroviral insertions within the EVI-1 locus are clustered within non-coding exon I or II and are frequently orientated in the same transcriptional direction. The mechanism of EVI-1 activation appears to be that of promoter insertion since viral derived transcripts are detectable. Bartholomew et al., [23] found a common retroviral integration site (CB-1) in two IL-3dependent cell lines (DA-3 and DA-34), 90kb upstream of the EVI-1 locus. This retroviral integration site closely linked to the EVI-1 locus is identical to the Fim-3 locus (Retroviral insertions within CB-1/Fim-3 were shown to activate expression of the EVI-1 gene from its normal promoter) [24]. Since no ribonucleic acid (RNA) expression was detectable from the viral long terminal repeat (LTR) within the Fim-3 region it suggests that the mechanism of EVI-1 activation may be that of a distal enhancer type. Ectopic expression of EVI-1 may therefore be due to retroviral insertion at either the Fim-3 or EVI-1 loci.

\section{EVI-1 PROTEIN - BIOLOGICAL EFFECT}

The biological functions of the EVI-1 gene both in normal cell proliferation/differentiation and in cellular transformation are unclear. The structural motifs identified in the EVI-1 protein is consistent with the protein being a transcription factor. Since transcription factors have been shown to act as transcription activators, repressors or both, similar functions have been assessed for the EVI-1 protein.

Studies have shown that EVI-1 protein acts as both a transcriptional repressor and activator [6]. Kreider et al. [25] showed in their study that EVI-1 protein blocks GATA-1 dependent transcriptional activation from expression constructs containing the $\mathrm{ZFi}$ consensus sequence in $\mathrm{NIH} 3 \mathrm{~T} 3$ cells, suggesting that EVI-1 acts as a transcriptional repressor via a DNA binding competition 
mechanism. Since GATA-1 and other members of the GATA family are expressed in haemopoietic cells it is conceivable that repression of some of the GATA target genes may contribute to leukaemogenesis [11]. However, Perkins and Kim, [26] stated in their study that no known physiological GATA sites are recognized by EVI1.

In a separate study, the AML-1 (currently refers to as RUNX1) - EVI-1 fusion protein, which contains the AML1 runt homology domain and the whole of EVI-1, fails to activate a minimal tk luciferase reporter construct containing PEBP2 (PEA2) binding sites upstream [27]. The AML1 protein acts as a trans-activator through the PEBP2 sites [27], which were originally identified in the polyomavirus enhancer [28]. There, the AML-EVI1 fusion protein antagonizes the wild type AML function, probably by a dominant negative mechanism. In addition, it also indicates that the EVI-1 protein is not a trans-activator protein, at least in this fusion and through this site. Fordham [11] also suggested that the EVI-1 protein can act as an active transcriptional repressor, as opposed to the probable passive repression mechanisms mentioned above, he also has shown that EVI-1 is able to actively repress the function of a strong trans-activator, VP 16, when targeted to the DNA either via the GAL4 1-147 DNA binding domain or alternatively through the wild-type $\mathrm{ZFi}$ recognition site.

In contrast, the EVI-1 protein has been shown to act as a transcriptional activator via binding to a consensus sequence GACCAGATAAGATAAN ${ }_{1-28}$ CTCATCTTC in both NIH3T3 and HEC-1B cells [29]. This sequence contains the consensus binding sequences for both ZFi and ZFii and suggests the possibility that the combination of these two binding sites may somehow alter the function of the EVI-1 protein, possibly by some conformational change. EVI-1 has also been shown to upregulate both the $c$-fos and $c$-jun promoters, although this might be an indirect effect. However, interestingly the upregulation of both promoters is dependent on the ZFii DNA binding domain $[30,31]$. Therefore, similar to other transcription factors it seems that the EVI-1 protein may be bifunctional. An in vivo target gene, designated 150-B, has been identified encoding a novel protein, which is suppressed in EVI-1 expressing myeloid cells [32].

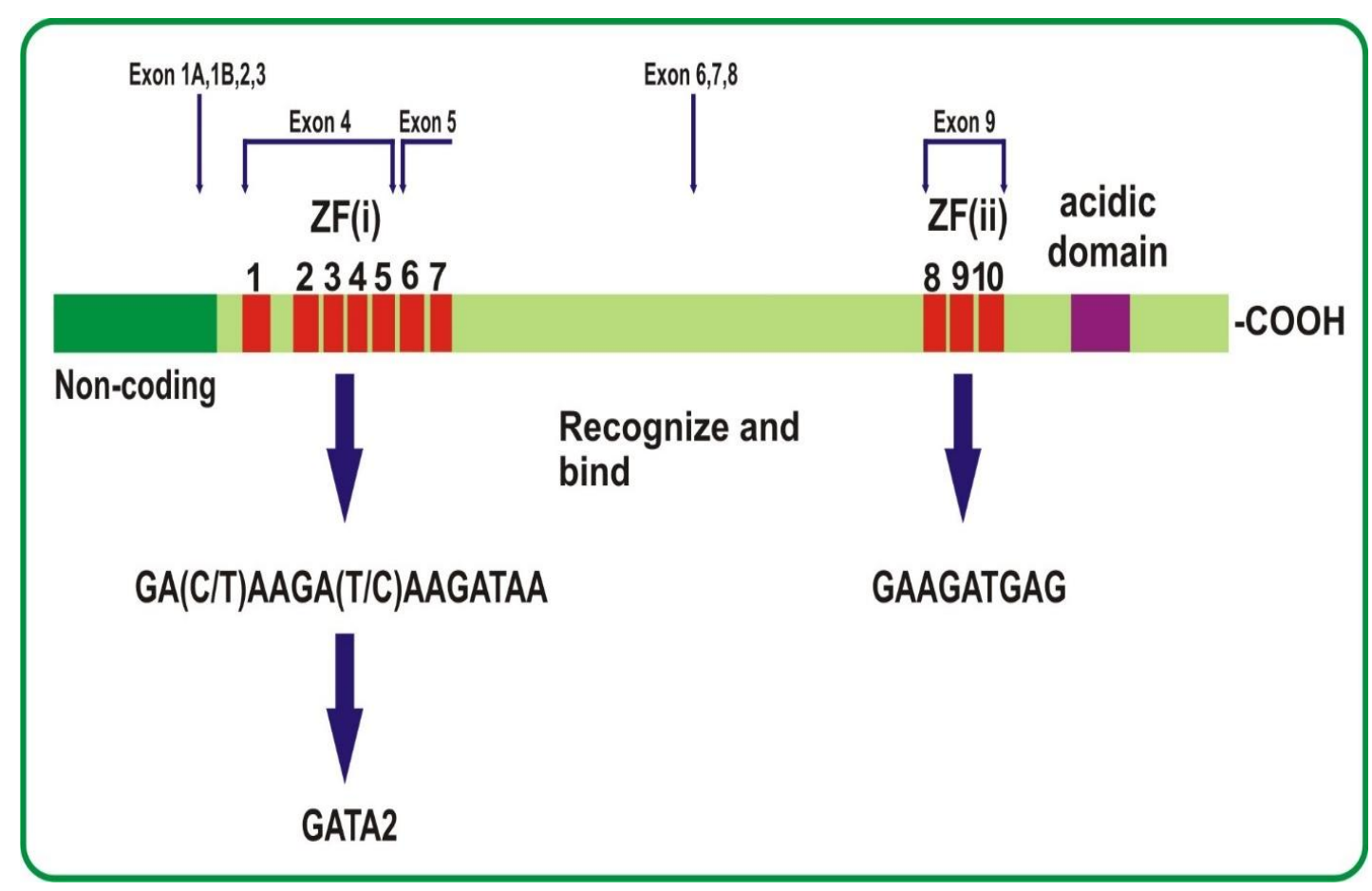

Fig. 1. Structure of alternatively spliced EVI-1, showing $\mathrm{N}$-terminal region that contains zinc finger domains (ZFi) and C-terminal region containing 3zinc finger domains (ZFii) and a sequence of acidic amino acid

(Adapted from Jolkowska et al, [17]; Yuan et al. [19] 
Okafor and Okoroiwu; ARRB, 36(1): 121-135, 2021; Article no.ARRB. 65245

Table 1. Selected families of zinc-finger domains

Zinc-domain type

$\mathrm{Cys}_{2}-\mathrm{His}_{2}$ (TFIIA)

Cys $_{2}-$ Cys $_{2}$ (GATA1)

$\mathrm{Cys}_{8}$ (Steroid thyroid receptor)

Cys $_{6}\left(\mathrm{GAL}_{4}\right)$

$\mathrm{Cys}_{2} \mathrm{HisCys}_{5}$ (LIM domain)

$\mathrm{Cys}_{2} \mathrm{HisCys}_{4}$ (Ring-finger)
Approximate consensus sequence

$\mathrm{C}-\mathrm{X}_{2-4}-\mathrm{C}-\mathrm{X}_{12}-\mathrm{H}-\mathrm{X}_{3-5} \mathrm{H}$

$\mathrm{C}-\mathrm{X}_{2}-\mathrm{C}-\mathrm{X}_{17}-\mathrm{C}-\mathrm{X}_{2} \mathrm{C}$

$\mathrm{C}-\mathrm{X}_{2}-\mathrm{C}-\mathrm{X}_{13} \mathrm{C}-\mathrm{X}_{2} \mathrm{C}-\mathrm{X}_{15} \mathrm{C}-\mathrm{X} 5-\mathrm{C}-\mathrm{X}_{12}-\mathrm{C}-\mathrm{X}_{4}-\mathrm{C}$

$\mathrm{C}-\mathrm{X}_{2}-\mathrm{C}-\mathrm{X}_{6}-\mathrm{C}-\mathrm{X}_{6}-\mathrm{C}-\mathrm{X}_{2}-\mathrm{C}-\mathrm{X}_{6}-\mathrm{C}$

$\mathrm{C}-\mathrm{X}_{2}-\mathrm{C}-\mathrm{X}_{17-19}-\mathrm{H}-\mathrm{X}_{2}-\mathrm{H}-\mathrm{X}_{2} \mathrm{C}-\mathrm{X}_{2}-\mathrm{C}-\mathrm{X}_{16-20}-\mathrm{C}-\mathrm{X}_{2-3}-\mathrm{C}$

$\mathrm{C}-\mathrm{X}_{2}-\mathrm{C}-\mathrm{X}_{9-27}-\mathrm{C}-\mathrm{X}_{1-3}-\mathrm{H}-\mathrm{X}_{2-3} \mathrm{C}-\mathrm{X}_{2}-\mathrm{C}-\mathrm{X}_{4-48}-\mathrm{C}-\mathrm{X}_{2}-\mathrm{C}$ Abbreviations: C; Cys, $H$; Hys, $X$; other amino acids Adapted from Berg \& Shi [33]
Function

Nucleic acid binding

DNA binding

DNA binding, Oligomerization

DNA binding

Protein/Protein interaction, DNA binding

Protein/Protein interaction, DNA binding 


\section{LEUKAEMONEGIC/ONCOGENIC ROLE OF EVI-1}

EVI-1 has been shown to be oncogenic. The oncogenic nature of the EVI-1 and AML1 (RUNX1)/EVI-1 fusion proteins, created as a result of the $(3 ; 21)$ translocation observed in chronic myelocytic leukaemias in blast crisis (CML-BC), has been assessed using the Rati transformation assay. In these experiments EVI-1 and $\mathrm{AML} 1 / \mathrm{EVI}-1$ have been shown to transform Rati cells, as measured by their ability to allow growth of the cells in soft agar. The introduction of deletion mutants of the AML1/EVI-1 fusion protein indicated that the EVI-1 ZFii domain was essential for the transforming activity [31]. In addition, Rati clones were established stably expressing the $B C R / A B L$ fusion protein (p210BCR/ABL), a characteristic of early chronic myelogeneous leukaemia (CML). These cells form macroscopic colonies in soft agar as described by others [34]. Interestingly, if p210BCR/ABLRATI cells were also transfected with constructs expressing the RUNX1/EVI-1 fusion an enhanced transformation was observed with larger and more numerous colonies formed in soft agar [31]. A recent study by Shen et al. [35] has shown that RUNX1-EVI-1 presented an intensive influence on haematopoietic regulatory factors. Consequently, primitive haematopoiesis was enhanced by upregulation of GATA2 and SCL, while erythropoiesis was downregulated due to the suppression of GATA1. They further stated that early stage of myelopoiesis was flourishing with the high expression of pu.1, but it was inhibited along with the low expression of MPO. Microarray analysis by Shen [35] and his coresearchers demonstrated that RUNX1-EVI-1 not only upregulated proteasome, cell cycle, glycolysis/ gluconeogenesis, tyrosine metabolism, drug metabolism, and PPAR pathway, but also suppressed transforming growth factor $\beta$, JAKSTAT, DNA replication, mismatch repair, p53 pathway, JNK signaling pathway and nucleotide excision repair. Furthermore, Cuenco and Ren [36] showed that bone marrow cells of murine transduced with EVI-1 alone cannot cause leukemia while Ichikawa et al. [37] illustrated that deletion of RUNX1 alone does not immortalize bone marrow cells which suggest that both suppression of RUNX1 and activation of EVI-1 are required for RUNX1-EVI-1 leukaemogenesis. It could be assumed that RUNX1-EVI-1 shares several molecular processes with wild-type EVI-1 and RUNX1 is more widely expressed in hematopoietic cells than EVI-1. It causes activation of EVI-1 function in hematopoietic cells, thus enhance cellular proliferation [235].

The involvement of the cellular EVI-1 gene in leukaemic progression led researchers like Matsugi et al. [32] and Perkins et al. [38] to evaluate the involvement of the gene in normal cell proliferation/differentiation. Initially, they examined the expression of the gene in murine tissues and cell lines by Northern blot analysis. These studies showed that high levels of EVI-1 expression were confined to kidney and developing oocytes, with lower levels identified in lung, uterus and heart, indicating that the EVI-1 gene has a restricted profile of expression in adult murine tissues suggesting that its expression might be important in the development of these organs [32,38]. In another study, EVI-1 also shows both temporal and spatial expression during murine embryonic development [38]. In situ hybridization experiments on mouse embryos identified high levels of EVI-1 expression in the urinary system and the Mullerian ducts, the bronchial epithelium of the lung; the endocardial cushions and truncus swellings in the heart; focal areas within the nasal cavities; and the developing limbs. The expression patterns of EVI1 are consistent with the gene being important in murine embryonic development. Similar data from EVI-1 knockout mice has confirmed the importance of EVI-1 in murine development. Homozygous EVI-1 knock out mice die in utero at day 10.5 post coitus ip.c.). The mutants have a complex phenotype but the most obvious abnormalities include widespread haemorrhage, the presence of large pericardial sacs, and disruption in the development of paraxial mesenchyme which is most obvious in the head. Furthermore, delayed development was observed in the kidney, heart and limb buds [11]. EVI-1, a nuclear transcription factor that contains DNAbinding zinc finger motifs also in addition to its DNA-binding activity, has been shown to possess the potential to recruit diverse proteins, such as Smad [39] and C-terminal Binding Protein (CtBP), thus generating regulatory complexes for transcriptional regulation [40].

\section{HUMAN LEUKAEMIAS AND EVI-1 PROTO-ONCOGENE - DIAGNOSTIC AND PROGNOSTIC IMPLICATIONS}

In humans, ectopic expression of the EVI-1 gene has been correlated with progression of some acute myelogenous leukaemias (AML), the closely related myelodysplastic syndromes (MDS) [40] and chronic myelocytic leukaemias in blast 
crisis (CML-BC) (6). Aberrant expression of EVI-1 has been reported in up to $10 \%$ of patients with AML, which can predict poor outcome as a diagnostic marker [41]. Studies have also shown that EVI-1 is barely expressed in normal hematopoietic cells, but it is overexpressed in chronic myelocytic leukemia in blastic crisis and myelodysplastic syndrome-derived leukemia [42].

AMLs are clonal malignancies characterized by abnormal proliferation and differentiation, resulting in the production of blast and other immature granulocytes, monocytes, erythroblast, and/or megakaryocytes. As with many leukaemias, lymphomas and some sarcomas [43], AML and MDS are associated with a number of recurring chromosomal abnormalities. Included in these are rearrangements at $3 q 26$ in about $2 \%$ of patients examined. EVI-1 is located on chromosome $3 q 26$, and rearrangements on chromosome $3 \mathrm{q} 26$ often activate EVI- 1 expression in haematological malignancies [40]. The most frequently observed chromosome translocations involving the 3q21q26 group of AMLs are inv(3)(q21q26) and $t(3 ; 3)(q 21 ; 26)$. Morishita et al. [44,45] and Suzukama et al. [18] indicated in their work that chromosomal breakpoints in 3q26 in these translocations have been located between 13-330kb $5^{\prime}$ and upto $150 \mathrm{~kb} 3$ ' of the gene. Characterization of the inv(3)(q21q26) breakpoint by these researchers suggests that ectopic expression of the EVI-1 gene may be a consequence of the gene being translocated to within the control of the enhancer elements associated with the Ribophorin I gene [18].

RUNX1 is essential for haematopoietic cell development in fetal liver as well as lineagespecific differentiation in adult liver. Point mutations of RUNX1 are relatively common in MOAML (12-33\%), MDS (23\%), and therapyrelated and radiation associated MDS/AML (38$46 \%$ [ [46]. RUNX1-EVI-1 chimeric gene is generated by the $t(3 ; 21)(q 26 ; q 22)$ translocation and also plays a pivotal role in progression of different hematopoietic stem cell malignancies (myelodysplastic syndrome, chronic myelogenous leukemia to acute blastic crisis phase, and acute myelogenous leukemia) $[40,44]$. Interestingly, this rare reciprocal translocation, $\mathrm{t}(3 ; 21)(\mathrm{q} 26 ; \mathrm{q} 22)$, event in CML-BC generates a fusion between the RUNX1 and EVI-1 genes which fuses the Nterminal runt homology domain of RUNX1 to the entire zinc-finger EVI-1 protein $[42,47]$. Takeshita et al. [48] demonstrated that the entire sequence of EVI-1 was required for transformation of primary bone marrow leukemia cells by RUNX1EVI-1. Growing evidences demonstrated that normal function loss of RUNX1/AML1 or abnormal activation of EVI-1 was an indicator of poor prognosis in leukemia [49-51]. And that RUNX1-EVI-1 fusion gene could enhance the malignant effectiveness [41].

In addition to CML-BC, the $\mathrm{t}(3 ; 21)$ translocation is also observed in MDS derived leukaemia [52] and the AML1-EVI-1 fusion transcript has also been detected in a MDS patient [47]. It has been postulated that $t(3 ; 21)$ translocation plays a critical role in leukaemic progression as haematopoietic stems cells transform to the acute leukaemic phase [53]. It has also been reported that ectopic expression of the EVI-1 gene in some MDS and other haematological malignancies appears to occur with no gross cytological abnormalities of chromosome 3q26 [13], suggesting that aberrant expression of this gene may result from various mechanisms. Susumu and Mineo [39] stated in their study that rearrangements on chromosome 3q26 often activate EVI-1 expression in haematological malignancies and that overexpression of EVI-1 also occurs with high frequency in leukaemia patients without $3 q 26$ abnormalities, and importantly, that high EVI-1 expression is an independent negative prognostic indicator irrespective of the presence of $3 q 26$ rearrangements. Interestingly, EVI-1 expression in some AMLs is also accompanied by chromosome 7 deletion [45,54]. This would appear to be a secondary event since, similar to 3q26 abnormalities, chromosome 7 deletion is often found in human leukaemias following treatment with alkylating agents [55]. Interestingly, leukaemias associated with 3q26 rearrangements involving EVI-1 often show megakaryopoiesis and elevated platelet counts [56], suggesting that EVI-1 might contribute to the progression of a distinct genetic disease. It should also be noted that rearrangements of $3 q 25$ or $3 q 27$ do not involve EVI-1 $[39,53]$.

Further studies also shows that EVI-1 overexpression blocks erythroid and myeloid differentiation and/or proliferation [11]. 32Dcl3 is a IL-3-dependent myeloid cell line that differentiates in response to G-CSF $[57,58]$. These cells have been used to examine the properties of proteins involved in differentiation, including c-Myb [59] and EVI-1 $[45,60]$. The introduction of retroviral constructs expressing the full length EVI-1 protein into the 32Dcl3 cells blocked the ability of the cells to differentiate in response to G-CSF. In support of these observations the same 


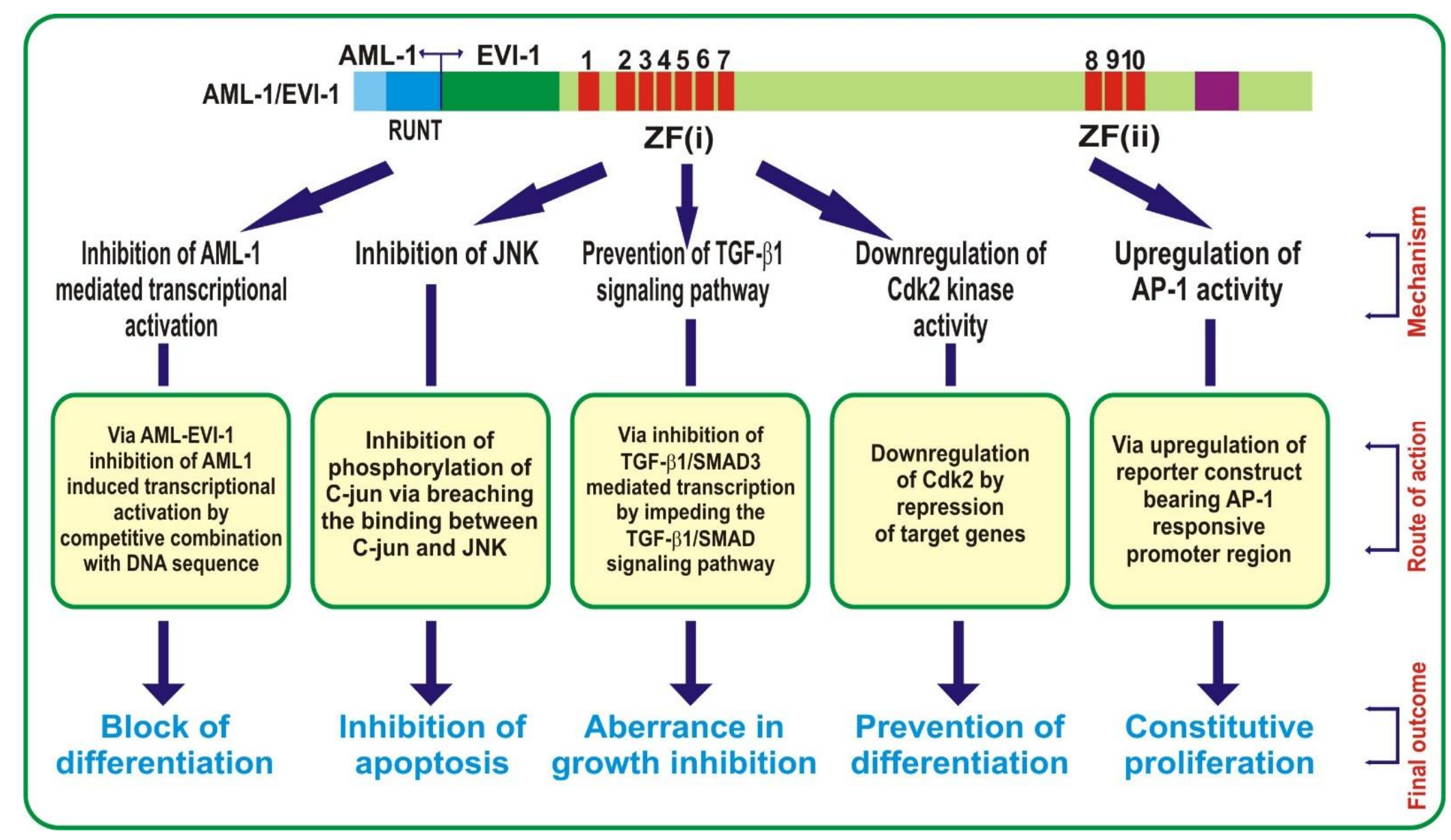

Fig. 2. Molecular mechanism of EVI-1 mediated leukaemogenesis (Adapted from Yuan et al. [19] 
Table 2. Examples of non-fusions from haematopoietic tumours

\begin{tabular}{|c|c|c|c|}
\hline Type & Affected gene & Disease & Rearranging gene \\
\hline $\begin{array}{l}\text { Basic-helix-loop helix } \\
\mathrm{t}(8 ; 14)(\mathrm{q} 24 ; \mathrm{q} 32 \\
\mathrm{t}(7 ; 19)(\mathrm{q} 35 ; \text { pl3) } \\
\mathrm{t}(\mathrm{l} ; 14)(\mathrm{p} 32 ; \mathrm{q} \mathrm{II}) \\
\mathrm{t}(7 ; 9)(\mathrm{q} 35 ; \mathrm{q} 34)\end{array}$ & $\begin{array}{l}c-M y c \text { (8q24) } \\
\text { LYL1 (19pl3) } \\
\text { TALI/SCL (Ip32) } \\
\text { TAL2 (9q34) }\end{array}$ & $\begin{array}{l}\text { BL, BL-ALL } \\
\text { T-ALL } \\
\text { T-ALL } \\
\text { T-ALL }\end{array}$ & $\begin{array}{l}\text { IgH, IgL } \\
\text { TCR- } \beta \\
\text { TCR- } \alpha \\
\text { TCR- } \beta\end{array}$ \\
\hline $\begin{array}{l}\text { LIM Proteins } \\
\text { t(II; 14)(pl5; q II) } \\
\text { t(II; 14)(pl3; q II) }\end{array}$ & $\begin{array}{l}\text { RBTNI/Ttgl (IIpl5) } \\
\text { RBTNI/Ttgl (IIpl5) }\end{array}$ & $\begin{array}{l}\text { T-ALL } \\
\text { T-ALL }\end{array}$ & $\begin{array}{l}\text { TCR- } \delta \\
\text { TCR- } \delta / \alpha / \beta\end{array}$ \\
\hline $\begin{array}{l}\text { Homeobox proteins } \\
\mathrm{t}(10 ; 14)(\mathrm{q} 24 ; \mathrm{q} \text { II) }\end{array}$ & Hoxll (10q24) & T-ALL & TCR $-\alpha / \beta$ \\
\hline $\begin{array}{l}\text { Zinc-finger proteins } \\
\mathrm{t}(3 ; 14)(\mathrm{q} 27 ; \mathrm{q} 32) \\
\operatorname{inv}(3)(\mathrm{q} 21 ; \mathrm{q} 26)\end{array}$ & $\begin{array}{l}\text { Laz3/BCL-6 (3q27) } \\
\text { Evi-1 (3q26) }\end{array}$ & $\begin{array}{l}\mathrm{NHL} / \mathrm{DLCL} \\
\mathrm{AML}\end{array}$ & $\mathrm{lg} H$ \\
\hline $\begin{array}{l}\text { Others } \\
\mathrm{t}(14 ; 18)(\mathrm{q} 32 ; 21) \\
\mathrm{t}(14 ; 19)(\mathrm{q} 32 ; \mathrm{q} \mid 3.1) \\
\mathrm{t}(3 ; 14)(\mathrm{q} 27 ; \mathrm{q} 32)\end{array}$ & $\begin{array}{l}\text { BCL2 (18q21) } \\
\text { BCL3 (19ql3.1) } \\
\text { TAN1 (9q34.3) }\end{array}$ & $\begin{array}{l}\text { FL } \\
\text { B-CLL } \\
\text { T-ALL }\end{array}$ & $\begin{array}{l}\lg \mathrm{H}, \lg \mathrm{L} \\
\lg \mathrm{H} \\
\mathrm{TCR}-\beta\end{array}$ \\
\hline
\end{tabular}

Table 3. Examples of fusions-proteins from haematopoietic tumours

\begin{tabular}{|c|c|c|c|}
\hline Type & Affected gene & Protein domain & Disease \\
\hline $\mathrm{t}(\mathrm{l} ; 19)(\mathrm{q} 23 ; \mathrm{q} \mid 3.3)$ & $\begin{array}{l}P B X 1 \text { (lq23) } \\
E 2 A(19 p \mid 3.3)\end{array}$ & $\begin{array}{l}\text { Homeodomain } \\
\text { AD-b-HLH }\end{array}$ & $\begin{array}{l}\text { pre-B-ALL } \\
\text { APL }\end{array}$ \\
\hline $\mathrm{t}(15 ; 17)(\mathrm{q} 21 ; \mathrm{qll}-22)$ & $\begin{array}{l}P M L(15 \mathrm{q} 21) \\
R A R a(17 \mathrm{q} 21)\end{array}$ & $\begin{array}{l}\text { Zinc-finger } \\
\text { Zinc-finger }\end{array}$ & \\
\hline $\mathrm{t}(3 ; 21)(\mathrm{q} 26 ; \mathrm{q} 22)$ & $\begin{array}{l}A M L 1(21 q 22) \\
E V I-1(3 q 26)\end{array}$ & $\begin{array}{l}\text { DNA binding/runt homology } \\
\text { Zinc-finger }\end{array}$ & $\begin{array}{l}\text { AML } \\
\text { AML }\end{array}$ \\
\hline $\mathrm{t}(8 ; 21)(\mathrm{q} 22 ; \mathrm{q} 22)$ & $\begin{array}{l}\text { AML1 (21q22) } \\
\text { ETO (8q22) }\end{array}$ & $\begin{array}{l}\text { DNA binding/runt homology } \\
\text { Zinc-finger }\end{array}$ & AML \\
\hline $\mathrm{t}(3 ; 21)(\mathrm{q} 26 ; \mathrm{q} 22)$ & $\begin{array}{l}\text { AML1 (21q22) } \\
\text { EAP (3q26) }\end{array}$ & $\begin{array}{l}\text { DNA binding/runt homology } \\
\text { Sn protein }\end{array}$ & AML \\
\hline $\mathrm{t}(3 ; 8)(\mathrm{q} 26 ; \mathrm{q} 22)$ & $\begin{array}{l}\text { EVI-1 (3q26) } \\
\text { ETO (8q22) }\end{array}$ & $\begin{array}{l}\text { Zinc-finger } \\
\text { Zinc-finger }\end{array}$ & AML \\
\hline t(16;21)(pll; q22) & $\begin{array}{l}\text { FUS (16p 11) } \\
\text { ERG (21q22) }\end{array}$ & $\begin{array}{l}\text { RNA binding } \\
\text { Ets protein }\end{array}$ & AML \\
\hline $\mathrm{t}(6 ; 9)(\mathrm{p} 23 ; \mathrm{q} 34)$ & $\begin{array}{l}\text { DEK (6p23) } \\
\text { CAN (9q34) }\end{array}$ & ?eucine zipper & AML \\
\hline
\end{tabular}

experiments have also been performed with the AML 1/EVI-1 fusion protein by a separate group, with the same conclusions [27]. However, Khanna-Gupta et al. [59] contradicts some of these previous observations made using the 32Dcl3 cells. They stated that 32Dcl3 cells were found to constitutively express high levels of EVI1 protein and secondly the cells were still able to respond to G-CSF. The authors also showed that further overexpression of EVI-1 in 32Dcl3 cells using retroviral EVI-1 expression vectors prevents the cells from responding to G-CSF, which is consistent with previous observation made by Morishita et al. [45]. Consequently, they proposed that it is the level of EVI-1 expression in myeloid cells, rather than ectopic expression, which is the 
most important determinant in contributing to leukaemic progression [60].

Similar, experiments have evaluated the response to erythropoietin (EPO) of normal mouse bone marrow progenitor cells [58] following infection with retroviral EVI-1 expression vectors [25]. The results showed that ectopic EVI1 expression was able to block growth of EPO responsive cells. However, it is not clear in these experiments whether the cells were unable to differentiate, proliferate or nonviable. In addition, the significance of this result to leukaemogenesis is unclear since the $A M L$ and CML-BC leukaemias, associated with ectopic EVI-1 expression, are generally associated with increased rather than decreased proliferation. However, recent gene targeting studies in mice by researchers revealed that $\mathrm{EVI}-1$ is preferentially expressed in hematopoietic stem cells and plays an essential role in proliferation and maintenance of haematopoietic stem cells. In addition, they also showed that transcription activating integrations into the EVI-1 locus confer survival and self renewing ability to haematopoietic cells. The experimental results using animal models suggest that activation of EVI-1 in haematopoietic cells leads to clonal expansion or dysplastic haematopoiesis, whereas onset of full-blown leukaemia requires cooperative genetic events $[32,43]$.

Glass et al. [50] in their work found disruption of terminal myeloid differentiation and cell cycle regulation to be prominent in EVI-1-induced leukaemogenesis while Yuasa et al. [62] showed that EVI-1 promoted early haematopoietic development in the P-Sp region, which seemed to depend on activation of GATA2 and repression of TGF- $\beta$ signaling, while ZFi of EVI-1 directly recognized and banded to the GATA2 promoter. GATA2 is a zinc finger transcription factor which is required for proliferation and maintenance of haematopoietic progenitor cells [63]. Researchers have found that GATA2 is aberrantly expressed in $87 \%$ of de novo AML cases, they also noted that correlation between EVI-1 and GATA2 expression were found in $A M L$ patients $[50,64]$. They therefore postulated that it's possible that GATA2 plays a crucial role in RUNX1-EVI-1 or EVI-1induced leukemogenesis.

Likewise, EVI-1 interacts with pu.1 and repressed the pu.1-dependent activation of a myeloid promoter [65]. Using mouse model Laricchia-Robbio et al. [66] reported that constitutive expression of EVI-1 in the bone marrow led to fatal anaemia and myeloid dysplasia, and EVI-1 interaction with GATA1 blocks proper erythropoiesis. Shen et al. [35] on the other hand found that more than $50 \%$ of RUNX1-EVI-1 positive cells were in the S/G2 period and no sub-G1 peak, which demonstrate apoptosis resistant and weak efficacy of G1 arrest. Mitani [42] in his study listed at least four mechanisms identified in AML1/EVI-1 fusion protein that possibly lead into malignant transformation of haematopoietic stem cells. First, he postulated that AML1/EVI-1 exerts dominantnegative effects over AML1-induced transcriptional activation. Although target genes repressed by $A M L 1 / E V I-1$ are still not known, binding competition to a specific DNA sequence and histone deacetylase recruitment through a co-repressor C-terminal Binding Protein (CtBP) in EVI-1 part are conceivable underlying mechanisms for the dominant-negative effects. Secondly, AML1/EVI-1 interferes with TGFb signaling and antagonizes the growth-inhibitory effects of TGFb. The first zinc-finger domain of EVI-1 associates with Smad3, a TGFb signal transducer, and represses its transcriptional activity by recruiting histone deacetylase through CtBP that interacts with EVI-1. Thirdly, AML1/EVI1 blocks JNK activity and prevents stress-induced apoptosis. AML1/EVI-1 associates with JNK through the first zinc-finger domain of EVI-1 and disturbs the association between JNK and its substrates and lastly, he stated that AML1/EVI-1 enhances AP-1 activity by activating the c-Fos promoter depending on the second zinc-finger domain of EVI-1, and promotes cell proliferation. All these functions cooperatively contribute to the malignant transformation of the haematopoietic stem cells by AML1/EVI-1 [42]. Current evidence suggests that leukemias are maintained by rare stem cells (Leukaemic stem cell), and that elimination of leukaemic stem cell is necessary and potentially sufficient for cure of the leukaemia but activation of EVI-1 has been shown to enhance proliferation and/or survival of leukaemic stem cell and thus, confers drug resistance on various types of leukemia [40].

EVI-1 expression level has been found to be an independent prognostic marker for complete remission, overall survival, relapse free and event free survival in AML patients irrespective of the mutation involved. AML patients with EVI-1 overexpression has lower rate of complete remission $(50 \%)$, overall survival $(20 \%)$, relapse free survival (10\%) and event free survival $(<10 \%)$ [67-70]. In another study, Groschel and Colleagues divided $\mathrm{AML}$ patient with $\mathrm{t}(9 ; 11)$ into 
two based on the EVI-1 expression. The outcome splitted them into favourable and unfavourable subgroups. Over expression of EVI-1 was associated with unfavourable category [71]. More so, increased EVI-1 expression has been associated with paediatric $11 \mathrm{q} 23$ rearranged $\mathrm{AML}$ which has been established to have adverse outcome [72-74]. Brooks et al. [72] in their study noted that EVI-1 is overexpressed in ovarian cancer compared with normal ovaries, suggesting a role for EVI-1 in solid tumour carcinogenesis or progression. Mechanisms underlying EVI- 1 overexpression in this instance was also attribute to the possible rearrangements involving chromosome 3q26.

\section{CONCLUSION}

Many studies have established that ectopic expression of EVI-1 is an important determinant in the progression of some leukaemias and high EVI-1 expression is observed in established myeloid cell lines as we have tried to illustrate in this review. We are therefore postulating that routine monitoring of EVI-1 gene in patients with these cancers can help immensely in monitoring response to treatment and treatment outcomes.

\section{FUNDING}

This article was funded by the TETFUND Nigeria (Institutional based research grant 2018)

\section{COMPETING INTERESTS}

Authors have declared that no competing interests exist.

\section{REFERENCES}

1. Ferlay $J$, Shin $H$, Bray $F$, Forman $D$, Mtthers C, Parklin DM. Estimates of World Wide Burden of Cancer in 2008: GLOBOCAN 2008, Int. J Cancer. 2010; 127(12):2893-917.

2. Jemal A, Siegel R, Ward E, Hao Y, Xu J, Murray $\mathrm{T}$, et al. Cancer statistics. CA Cancer J Clin. 2008;58(2):71-96.

3. Haen J. Principle of haematoly. Boston: W.M.C. $\quad$ Brown Publishers; 1995.

4. Matsuo H, Kajihara M, Tomizawa D, Watanabe T, Saito. AM, Fajimoto J, et al. EVI1 overexpression is a poor prognostic factor in pediatric patients with mixed lineage leukemia-AF9 rearranged acute myeloid leukemia. Haematologica. 2014;99:e225-e227.

5. Brooks DJ, Woodward S, Thompson FH, B Dos Santos', Russell M, Yang J-M, Guan2 X-Y, Trent2J, Alberts DS, Taetle R. Expression of the zinc finger gene EVI-1 in ovarian and other cancers Britsh Journal of Cancer. 1996;74:1518-1525.

6. Neumann E. Ueber die bedeutung des knockenmarke fur die blutbildung. Ein Beitrag zur Entwicklungsgeschichte der Blutkorperchen. Archives Heikunde 1869; 10:68-102.

7. Erlich P. Methodologische Beitrage Zur Physiologie und Pathologie der Verschisdenen Formen; 1880.

8. Groschel S, Lugthart S, Schlenk RF, Valk PJ, Elwen K, Goudsward C, et al. High EVI1 expression predicts outcome in younger adult patients with acute myeloid leukemia and is associated with distinct cytogenetic abnormalities. Journal of Clinical Oncology. 2010;28:2101-2107.

9. Lugthart $S$, Van Drunen E, Norden $Y$, Van Hoven A, Erpelinck CA, Valk PJ, et al. High EVI-1 level predicts adverse outcome in acute myeloid leukemia: prevalence of EVI1 overexpression and chromosome 3q26 abnormalities underestimated Blood. 2008;111:4329-4337.

10. Dohner H, Estey EH, Amadori $S$, Appelbaum FR, Buchner T, Burnett AK, et al. Diagnosis and management of acute myeloid leukemia in adults: recommendations from an international expert panel on behalf of the European LeukemiaNet. Blood, 2008;115:453-474.

11. Fordham JL. Transcriptional Regulation of the EVI-1 gene PhD Thesis Beatson Institute for Cancer Research University of Glasgow; 1996.

12. Morishita K, Parker DS, Mucenski ML, Jenkins NA. Retroviral activation of a novel gene encoding a zinc finger protein in IL-3dependent myeloid leukemia cells lines. cell 1988;54:831-840.

13. Russel M, List A, Greenberg P, Woodward S, Glinsmannn B, Parganas E, et al. Expression of EVI1 in myelodysplastic syndromes and other haematologic malignancies without $3 q 26$ translocations. Blood. 1994;84:1243-1248.

14. Groschel S, Schlenk RF, Engelmann K, Rockova V, Teleanu V, Kuhn MW, et al. Deregulated subset of MLL-rearranged acute myeloid leukemia: A case study of 
the German-Austrain acute myeloid leukemia study group and the dutchbelgian_swiss HOVON/SAKK Cooperative. 2013;31:95-103.

15. Jo A, Mitani S, Shiba N, Hayashi Y, hara Y, Takahashi $\mathrm{H}$, et al., High expression of EVI1 and MEL-1 is a compelling poor prognostic marker of pediatric AML. Leukemia. 2015;29:1076-1083.

16. Ho PA, Alonzo TA, Gerbing RB, Pollard JA, Hirsch B, Raimondi SC, et al. High EVI-1 is associated with MLL rearrangements and predicts decreased survival in pediatric acute myeloid leukemia: a report from the children's onology group. British Journal of Haematology. 2013;162: 670-677.

17. Jolkowska J, Witt M. The EVI-1 gene-its role in pathogenesis of human leukemias. Leukemia Research. 2000;24:553558.

18. Suzukawa K, Taki $\mathrm{T}$, Abe $\mathrm{T}$, Asoh $\mathrm{H}$, Kamada N, Yokota J, et al. Identification of translocation breakpoints within the intron region before the last coding exon (exon 12) of the EVI-1 gene in two cases of CMLBC with inv(3) (q21q26). Genomics. 1997; 42: 356.

19. Yuan $X$, Wang $X, B i ~ K$, Jiang $G$. The role of EVI-1 in normal hematopoiesis and myeloid malignancies. International Journal of Oncology. 2015;47:2028-2038.

20. Delwel R, Funabiki T, Kreider BL, Morishita $\mathrm{K}$, Ihle. Four of the seven zinc fingers pof the EV1 myeloid-transforming gene are required for sequence-specific binding to GA(CT)AAGA(T/C)AAGATAA. Mol Cell Biol. 1993;13:4291-4300.

21. Mucenski ML, Taylor BA, Ihle JN, Hartley JW, Morse III HC, Jenkins NA. Identifcation of a common site of viral integration site, EVI-1, in the DNA of AKXD murine myeloid tumours. Mol. Cell. Biol. 1988;8:301-308.

22. Bergeron D, Poliquin L, Houde J, Barbeu B, Rassart E. Analysis of proviruses integrated in the Fli-1 and EVI-1 regions in Cas-Br-E MuLV-induced non-T, non-B-cell leukaemias. Virology. 1992;191:661-669.

23. Bartholomew C, Morishita K, Askew D, Buchberg A, Jenkins NA, Copeland NG, et al. Retroviral intsertions in the CB-I/Fim-3 common site of integration activate expression of the EVI-1 gene. Oncogene. 1989;4:529-534.

24. Bartholomew C, Ihle JN. Retroviral insertions 90 kilobases to the EVI-1 myeloid transforming gene activate transcription from the normal promoter. Mol. Cell. Biol. 1991;11:1820-1828.

25. Kreider BL, Orkin SH, Ihle JN. Loss of erythropoietin responsiveness in erythroid progenitors due to expression of the EVI-1 myeloid-transforming gene. Proc Natl Acad Sci USA. 1993;90:6454-8.

26. Perkins AS, Kim JH. Zinc-fingers 1-7 of EVI-1 fail to bind the GATA motif by itself but require the core site GACAAGATA for binding. J. Biol. Chem. 1996;271:11041110.

27. Tanaka T, Mitani K, Kurokawa M, Ogawa S, Tanaka K, Nishida J, et al. Dual functions of the AMLI/EVI-1 chimeric protein in the mechanism of leukaemogenesis in $t(3 ; 21)$ leukaemias. Mol. Cell. Biol. 1995;15:23832392.

28. Piette J, Yaniv M. Two diffrent factors bind to the a-domian of the polyoma virus enhancer, one of which also interacts with the SV40 and c-fos enhancers. EMBO. J. 1987;6:1331-1337.

29. Morishita K, Suzukawa K, Taki T, Ihle JN, Yokota J. EVI-1 zinc finger protein works as a transcriptional activator via binding to a consensus sequence of GACAAGATAAGATAAN1-28

CTCATCTTC. Oncogene 1995;10:1961-7.

30. Tanaka T, Nishida J, Mitani K, Ogawa S, Yazaki Y, Hirai H. EVI-1 raises AP-1 activity and stimulates c-fos promoter transactivation with dependence no the second zinc finger domain. 1994;269:24020-24026.

31. Kurokawa M, Ogawa S, Tanaka T, Mitani, $\mathrm{K}$, Yazaki Y, Witte ON, et al. The AMLI/EVI1 fusion protein in the $t(3 ; 21)$ translocation exhibits transforming activity of Rati fibroblasts with dependence on the EVI-1 sequence. Oncogene. 1995;11:833-840.

32. Matsugi $\mathrm{T}$, Morishita $\mathrm{K}$, Ihle JN. Identification, nuclear localization, and DNA-binding activity of the zinc finger protein encoded by the EVI-1 myeloid transforming gene. Mol Cell Biol 1990; 10:1259-64.

33. Berg JM, Shi Y. The galvanisation of biology: a growing appreciation for the role of zinc. Science. 1996;271:1081-1085.

34. Lugo TG, Witte ON. The BCR-ABL oncogene transforms RAT-1 cells and cooperates with vmyc.Mol. Cell. Biol. 1989; 9:1263-1270.

35. Shen L, Zhu J, Chen F, Lin W, Cai J, Zhong $\mathrm{J}$ and Zhong $\mathrm{H}$. RUNX1-EVI-1 fusion gene 
inhibited differentiation and apoptosis in myelopoiesis: an in vivo study. BMC Cancer 2015;15:970.

36. Cuenco GM, Ren R. Both AML1 and EVI1 oncogenic components are required for the cooperation of AML1/MDS1/EVI1 with $\mathrm{BCR} / \mathrm{ABL}$ in the induction of acute myelogenous leukemia in mice. Oncogene. 2004;23(2):569-79.

37. Ichikawa $M$, Asai $T$, Saito $T$, Seo $S$, Yamazaki I, Yamagata T, et al. AML-1 is required for megakaryocytic maturation and lymphocytic differentiation, but not for maintenance of hematopoietic stem cells in adult hematopoiesis. nature medicine. 2004;10(3):299-304.

38. Perkins AS, Fishel $R$, Jenkins NA, Copeland NG. EVI-1, a murine zinc finger proto-oncogene, encodes a sequencespecific DNA-binding protein. Mol Cell Biol. 1991;11: 2665-74.

39. Morishita K, Parganas E, Douglass EC, Ihle $\mathrm{JN}$. Unique expression of the human EVI-1 gene in an endometrial carcinoma cell line: sequence of cDNAs and structure of alternatively spliced transcripts. Oncogene 1990;5:963-71.

40. Susumu Goyama and Mineo Kurokawa. Pathogenetic significance of ecotropic viral integration site-1 in hematological malignancies. Cancer Sci. 2009;100(6): 993.998.

41. Lugthart $S$, Van Drunen E, Van Norden $\mathrm{Y}$, Van Hoven A, Erpelinck CA, Valk PJ, et al. High EVI1 levels predict adverse outcome in acute myeloid leukemia: prevalence of EVI1 overexpression and chromosome 3q26 abnormalities underestimated. Blood. 2008;111(8):4329-37.

42. Mitani K. Molecular mechanisms of leukemogenesis by AML1/EVI-1. Oncogene. 2004;23(24):4263-9.

43. Rowley JD. Recurring chromosome abnormalities in leukaemia and lymphoma. Semin Hematol. 1990;27:122.

44. Morishita K, Parganas E, Matsugi T, Ihle $\mathrm{JN}$. Expression of the EVI-1 zinc finger gene in 32Dcl3 myeloid cells blocks granulocytes differentiation in response to granulocyte colony-stimulating factor. Mol. Cell. Biol. 1992;12:183-189.

45. Morishita K, Parganas E, Willman CL, Whitaker $\mathrm{MH}$, Drabkin $\mathrm{H}$, Oval $\mathrm{J}$, et al. Activation of the EVI-1 gene expression in human acute myeloid leukaemias by translocations spanning 300-400 kilobases on chromsome band 3q26. Proc. Natl. Acad. Sci. USA. 1992;89:3937-3941.

46. Harada $H$, Harada $Y$, Niimi $H$, Kyo $T$, Kimura A, Inaba T. High incidence of somatic mutations in the AML1/RUNX1 gene in myelodysplastic syndrome and low blast percentage myeloid leukemia with myelodysplasia. Blood. 2004;103(6):231624

47. Mitani K, Ogawa S, Tanaka T, Miyoshi H, Kurokawa M, Mano H, et al. Generation of the AML 1-EVI-1 fusion gene in the $t(3 ; 21)$ (q26;q22) causes blastic crisis in chronic myelocytic leukaemia. EMBO. 1994;504510.

48. Takeshita M, Ichikawa M, Nitta E, Goyama $\mathrm{S}$, Asai T, Ogawa $\mathrm{S}$, et al. AML1-EVI-1 specifically transforms hematopoietic stem cells through fusion of the entire EVI-1 sequence to AML1. Leukemia. 2008;22(6):1241-9

49. Sasaki K, Yamagata T, Mitani K. Histone deacetylase inhibitors trichostatin $\mathrm{A}$ and valproic acid circumvent apoptosis in human leukemic cells expressing the RUNX1 chimera. Cancer science. 2008;99(2):414-22.

50. Glass C, Wuertzer C, Cui X, Bi Y, Davuluri $\mathrm{R}$, Xiao $\mathrm{YY}$, et al. Global Identification of EVI1 Target Genes in Acute Myeloid Leukemia. PloS one. 2013;8(6):67134.

51. Kumano K, Kurokawa M. The role of Runx1/AML1 and EVI-1 in the regulation of hematopoietic stem cells. Journal of Cellular Physiology. 2010;222(2):282-5.

52. Rubin CM, Larson RA, Anastasi J, Winter $\mathrm{JN}$, Thangavelu $\mathrm{M}$, Vardiman, $\mathrm{J}$, et al. $\mathrm{t}(3 ; 21)(\mathrm{q} 26 ; \mathrm{q} 22)$ : a recurring chromosomal abnormality in therapy related myelodysplastic sundrome and acute myeloid leukaemia. Blood. 1990;76:25942598.

53. Chen Z, Morgan R, Baer MR, Ligorsky R, Sandberg AA. Translocation (3;21) characterizes crises in myeloid stem cell disorders. Cancer. Gener. Cytogenet. 1991; 57:153-159.

54. Fichelson S, Dreyfus F, Berger R, Melle J, Bastard C, Miclea M, et al. EVI-1 expression in leukaemic patients with rearrangements of thew 3q25-q28 chromosomal region. Leukaemia. 1992; 6:93-99.

55. LeBeau M, Albain KS, Larson RA, Vardimam, JW, Davis EM, Blough RR, Et 
al. Clinical and cytogenetical correlations of 63 pateints with therapy related myelodysplastic syndromes abd acute nonlymphocytic leukaemia: Furhter evidence for characteristic abnormalites of chromosome no. 5 and 7. J. Clin. Oncol. 1986;8:325.

56. Bitter M, Neilly M, LeBeau M, Pearson M, Rowley J. Rearrangements of chromsome 3 involving bands $3 q 21$ and $3 q 26$ are associated with normal and elevated platelet counts in acute nonlymphocytic luekaemia. Blood. 1985;66:1362-1370.

57. Greenberger JS, Sakakeeny MA, Humphries RK, Eaves CJ, Eckner RJ. Demonstration of permanent factordependent mutipotential (erythroid/ neutrophil/basophil) haematopoietic progenitor cell lines. Proc. Natl. Acad. Sci. USA. 1983;80:2931-2935.

58. Migliaccio G, Migliaccio A, Kreider B, Rovera G, Adamson J. Selection of lineage restricited cell lines immortalised at different stages of heamopoietic differentiation from the murine cell line 32D. J. Cell. Biol. 1989; 109:833-841.

59. Otten A, Saunders M, McKnight G. Molecular endocrinology. 1988;2:143-147.

60. Khana Gupta A, Lopingo MC, Savinelli T, Zibello T, Berliner N, Perkins AS. Retroviral insertional activation of the $E \mathrm{~V}$ II oncogene does not prevent G-CSF-induced maturation of the mrine pluripotent myeloid cell line 32Dcl3. Oncogene. 1996;12:563569.

61. Rabbits TH. Chromosomal translocations in human cancer. Nature. 1994; 372:143149.

62. Yuasa $\mathrm{H}$, Oike $\mathrm{Y}$, Iwama A et al. Oncogenic transcription factor Evi1 regulates hematopoietic stem cell proliferation through GATA-2 expression. EMBO J. 2005;24:1976-87

63. Paik EJ, Zon LI. Hematopoietic development in the zebrafish. The International Journal of Developmental Bio logy. 2010;54(6-7):1127-37.

64. Shimamoto T, Ohyashiki JH, Ohyashiki K, Kawakubo K, Kimura N, Nakazawa S, et al. GATA-1, GATA-2, and stem cell leukemia gene expression in acute myeloid leukemia. Leukemia. 1994;8(7):1176-80.

65. Matsuo $H$, Kajihara $M$, Tomizawa $D$, Watanabe T, Saito AM, Fajimoto J, et al. EVI1 overexpression is a poor prognostic factor in pediatric patients with mixed lineage leukemia-AF9 rearranged acute myeloid leukemia. Haematologica. 2014; 99: 225-227.

66. Laricchia Robbio L, Premanand K, Rinaldi CR, Nucifora G. EVI1 Impairs myelopoiesis by deregulation of PU.1 function. Cancer Res. 2009; 69(4):1633-42.

67. Hincui AA, Valk PJM. Review: Abberant EVI-1 expression in acute myeloid leukemia. British Journal of Haematology. 2016;172(6):870-878.

68. Groschel S, Lugthart S, Schlenk RF, Valk PJ, Elwen K, Goudsward C, et al. High EVI1 expression predicts outcome in younger adult patients with acute myeloid leukemia and is associated with distinct cytogenetic abnormalities. Journal of Clinical Oncology. 2010;28:2101-2107.

69. Lugthart S, Van Drunen E, Norden Y, Van Hoven A, Erpelinck CA, Valk PJ, et al. High EVI-1 level predicts adverse outcome in acute myeloid leukemia: prevalence of EVI1 overexpression and chromosome 3q26 abnormalities underestimated Blood. 2008; 111: 4329-4337.

70. Dohner $\mathrm{H}$, Estey $\mathrm{EH}$, Amadori $\mathrm{S}$, Appelbaum FR, Buchner T, Burnett AK, et al. Diagnosis and management of acute myeloid leukemia in adults: Recommendations from an international expert panel on behalf of the European Leukemia Net. Blood. 2008;115:453474.

71. Groschel S, Schlenk RF, Engelmann K, Rockova V, Teleanu V, Kuhn MW, et al. Deregulated subset of MLL-rearranged acute myeloid leukemia: A case study of the German-Austrain acute myeloid leukemia study group and the DutchBelgian_Swiss HOVON/SAKK Cooperative. 2013; 31: 95-103.

72. Brooks DJ, Woodward S, Thompson FH, Dos Santos' B, Russell M, Yang JM, et al. Expression of the zinc finger gene EVI-1 in ovarian and other cancers. Britsh Journal of Cancer. 1996;74:1518-1525.

73. Jo A, Mitani $S$, Shiba $N$, Hayashi $Y$, hara $Y$, Takahashi $\mathrm{H}$, et al., High expression of EVI1 and MEL-1 is a compelling poor prognostic marker of pediatric AML. Leukemia. 2015; 29:1076-1083.

74. Ho PA, Alonzo TA, Gerbing RB, Pollard JA, Hirsch B, Raimondi SC, et al. High EVI-1 is associated with MLL rearrangements and 
predicts decreased survival in pediatric acute myeloid leukemia: a report from the children's onology group. British Journal of Haematology. 2013;162:670-677.

(c) 2021 Okafor and Okoroiwu; This is an Open Access article distributed under the terms of the Creative Commons Attribution License (http://creativecommons.org/licenses/by/4.0), which permits unrestricted use, distribution, and reproduction in any medium, provided the original work is properly cited.

Peer-review history:

The peer review history for this paper can be accessed here:

http://www.sdiarticle4.com/review-history/65245 